\title{
Family law and its discontents
}

\section{Inaugural professorial lecture}

\author{
John Dewar
}

\section{Introduction}

There are few areas of law that generate as much controversy and disagreement as family law. It's something potentially that affects us all, in which we all feel we have a stake and of which some of us have had direct experience. Indeed, there are probably few areas of law that affect so many people so directly in their every day lives. Yet it is probably also true that nowhere is the authority or legitimacy of law more often called into question.

Against this rather unpromising background for a public lecture on the topic, I want to do two things this evening. First, I want to suggest that there is a pervasive uncertainty about what family law is for, how it is to set about its primary tasks, and how, if at all, family law should embody conventional notions of legality: and I will suggest that these uncertainties have led to tensions that find expression in contemporary family law. I will also suggest that these uncertainties and tensions have intensified in the last ten years, and I will try and explain how and why this has happened. In short, I will try to provide a map of what has

\footnotetext{
* BCL, MA (Oxon), Ph.D (Griff), Professor of Law and Director, Family Law Research Unit, School of Law, Griffith University. Much of the research for, and some of the writing of, this lecture was conducted during a period of study leave in the early part of 1999. I am grateful to Griffith University for releasing me for this purpose; and to the Principal and Fellows of Hertford College, Oxford, for generously providing me with a safe haven in which to work. I am also grateful to Henrietta Dewar for her comments on a previous draft of this lecture; to Ms Katherine Shann, a Griffith undergraduate law
} 
become a confused and tangled terrain of conflicting ideas and tendencies. In doing so, I have tried to develop a conceptual vocabulary that is adequate to that task of description.

My second task is probably more controversial, and at the same time probably more important - because I want to offer a defence of the role of law in family matters. I use the word 'defence' deliberately, because the role of law, and the institutions of law (such as the Family Court and legal practitioners), has come under sustained attack in recent times. It is suggested that family disputes are only exacerbated by law's involvement, and that the legal system consistently fails to deliver 'justice' to the parties who pass through it. These arguments are heard more and more frequently, and I suspect that they have yet to reach the peak of their intensity ${ }^{1}$. Yet it is not often that one hears the case in reply - the case, that is, for law, and for the values of procedural fairness and legality, that go with it. I do not pretend to have marshalled all the arguments that could be made on this (and I don't have much to say, because my ideas on this are still not as developed as they I would like) but I do want to suggest that in areas of radical disagreement, such as the terms on which families should separate, law (at least as a mode of

\footnotetext{
student, for her research assistance; and to my former research assistant, Tanya Denning, now of Blake Dawson Waldron.

${ }^{1}$ M.Kaye and J.Tolmie, 'Father's rights groups in Australia and their engagement with issues in family law' (1998) 12 Australian Journal of Family Law 19, esp. at pp.62-5 (discussing Men's Rights Groups' views on 'bias' in the Family Court and preferences for mediation to formal adversarial proceedings). Allegations of bias against men in family proceedings are not unique to Australia: see C.McNeely, 'Lagging behind the times: Parenthood, custody and gender bias in the family court' (1998) 25 Florida State University Law Review 891 (advocating, amongst other things, a statutory presumption in favour of joint physical or rotating custody of children and 'courtwatch' programmes to monitor the outcomes of contested custody proceedings). Pauline Hanson's One Nation's Family Law and Child Support Policy Directions (September 1998) states that ' $[\mathrm{t}]$ he Family Law Court (sic) should be abolished and replaced with a Family Tribunal...A Family tribunal would exclude legal interference and eradicate the current adversarial system' (available at http://www.onenation.com.au/policy/family1.html).
} 
reasoning and as a way of framing practical solutions to disagreement) is perhaps our only hope of finding common ground.

\section{Family law in transformation - again?}

Family lawyers are fond of announcing transformations in their discipline $^{2}$. When I first started studying the subject over 20 years ago, the transformation that was talked of then was that brought about by the shift from a fault to a no-fault regime of divorce. This transformation was widespread in the English-speaking jurisdictions, and in Australia was ushered in by the Family Law Act 1975 (Cth). The term 'transformation' was an appropriate way of describing that shift, in view of the root and branch nature of the change it brought about- not just to the grounds on which divorces were to be granted, but also to the way in which its consequences were to be determined. Indeed, the changes even went to the way in which the human participants in divorce proceedings were to be perceived - not as moral agents deserving of blame or credit, but as individuals in need of expert assistance.

Twenty years on, the language of transformation is being used again ${ }^{3}$. At the very least, there is a perception that the edifice of no fault divorce is beginning to crumble under the weight of a new set of ideas, techniques and assumptions. Yet unlike the introduction of no-fault divorce, quite what that new set of ideas might be has proved elusive to define. Instead, observers talk of 'arnarchy', 'chaos' and 'incoherence' as the order of the

\footnotetext{
${ }^{2}$ M.Glendon, State, Law and Family: Family Law in transition in the United States and Western Europe (1977, North-Holland); C.Schneider, 'Moral discourse and the transformation of American family law' (1985) 83 Michigan Law Review 1803; L.Teitelbaum, 'The last decades of American family law' (1996) 46 Journal of Legal Education 546.

${ }^{3}$ A.Bainham, 'Changing families and changing concepts - Reforming the language of family law' (1998) 10 Child and Family Law Quarterly 1 (suggesting that '[I]t would not be an exaggeration to say that over the last decade English family law has been transformed': at p.1).
} 
day, with the new ideas and techniques proving fragmented and uncoordinated, and in any case not entirely displacing the original model $^{4}$. All of this is dimly perceived as being linked to a 'crisis' in the family itself, although the story of that crisis is told in different ways that family life is more unstable (the narrative of decline $)^{5}$; that the conventional heterosexual nuclear family has too strong a grip on our social imagination and has 'familialised' (and therefore impoverished) our patterns of social and political organisation (the narrative of emancipation $)^{6}$; or that family instability is endemic in late modern societies, where the attenuation of traditional family ties has been replaced with a compulsive search for intimacy that can only disappoint (the narrative of reflexive modernity) ${ }^{7}$.

I want to offer a way of making sense of what is admittedly a highly complex picture. I will suggest that there are a number of ways in which the structure introduced in 1975 has been modified or displaced, but that at the same time there is no coherent model replacing it. One consequence of this is that it is impossible to talk of a 'transformation' of one body of thought, structures and institutions replacing another.

\footnotetext{
${ }^{4}$ I.Thery, "'The interests of the child" and the regulation of the post-divorce family' (1986) 14 International Journal of the Sociology of Law 341; S.Parker, 'Rights and utility in Anglo-Australian family law' (1992) 55 Modern Law Review 311; J.Dewar, 'The normal chaos of family law' (1998) 61 Modern Law Review 467.

${ }^{5}$ There is a considerable body of literature in the United States that lays the blame for currently high divorce rates and the seeming dissolution of traditional family structures at the door of no-fault divorce: for example, P.Swisher 'Reassessing fault factors in no-fault divorce' (1997) Family Law Quarterly 269. For a response, see I.Ellmann, 'The misguided movement to revive fault divorce, and why reformers should look instead to the American Law Institute' (1997) International Journal of Law, Policy and the Family 216.

${ }^{6}$ M.Barrett and M.McIntosh, The anti-social family (1982, Verso); R.Sennett, The fall of public man (1986, Faber);

${ }^{7}$ U.Beck, Risk Society: Towards a new modernity (Sage, 1992): ‘. . in the prevailing diluted social relationships, people are driven into bonding in the search for happiness in a partnership. The need for a shared inner life ... grows with the losses that individualisation brings as the obverse of its opportunities' (p.105). See also U.Beck and E.Beck-Gernsheim, The normal chaos of love (Polity, 1995).
} 
Instead, there is what is best described as an uneasy transition from a known past to an uncertain future. It is this state of affairs that, I will argue, gives rise to certain points of tension, the 'discontents' of my title.

I have identified four ways in which the assumptions, objectives or techniques of family law have been modified or displaced since 1975 . These are:

- the displacement of marriage as the central concept linking law to families, and the growth in the importance of other concepts such as cohabitation or parenthood;

- a reduced reliance on discretionary decision-making to more rule-like statutory provisions;

- a diversification in the sources of family law norms; and

- the fragmentation of the family law system itself.

It will become apparent that there is no single set of ideas or explanations lying behind these four trends, although there may be some loose connections between them. Instead, the patterns are diverse, fragmented and sometimes contradictory. At the same time, it is not easy to pinpoint when the changes began to take effect - 'somewhere in the late 1980s or early 1990s' is the best I can do. It may be that, in due course, it will be possible to look back and discern in all of this some master plan - but that point has not yet arrived. One further difficulty in describing trends in Australian family law stems from the fact that legislative authority in family law is split between the States and Territories, and the Commonwealth. This means that there is no single source of family law legislation, although there has been considerable co-operation between 
States and Territories in many matters falling outside Commonwealth power ${ }^{8}$. Even so, there are some noticeable variations in approach between different legislatures.

\section{(a) Organising concepts: marriage, cohabitation, parenthood}

How does the law 'see' families?' When the FLA 1975 was enacted, the answer to that question lay in marriage: marriage was the chief means by which families were linked to law. Marriage conferred a status, in the sense of rights not available to others, in private and public law ${ }^{10}$. There was only limited recognition of other forms of family organisation as having legal significance ${ }^{11}$. This can be explained in part as a consequence of the Commonwealth's limited powers to legislate only for 'marriage' and 'matrimonial causes'; but one suspects that even if the Commonwealth had wider powers to legislate for families, it would still have relied heavily, if not exclusively, on marriage in doing so. After all, legislation governing de facto relations did not appear in State law until 1984, and still does not exist in some States.

Marriage is a convenient conceptual device for making families visible in law, provided that most family life is conducted within marriage. The challenge facing legal policy in this area, however, has been the dramatic shift in attitudes and social practices in relation to non-marital cohabitation. Statistics show that Australians are marrying less, while

\footnotetext{
${ }^{8}$ And some referral of power to the Commonwealth: see below.

${ }^{9}$ The metaphor of sight is borrowed from J.Millbank, 'If Australian law opened its eyes to lesbian and gay families, what would it see?' (1998) 12 Australian Journal of Family Law 99.

${ }^{10}$ Marriage brought with it a certain number of automatic consequences in the areas of inheritance, contract, property, evidence and procedure, taxation and citizenship: see H.Finlay, Family Law in Australia (Butterworths, 1979). The implications of marriage (or its absence) for children was reduced by the removal of discriminatory legal treatment of children born outside marriage by State Status of Children legislation, enacted in most Australian jurisdictions in the mid-1970s.
} 
living together and having children outside marriage in larger numbers, than in the first half of this century ${ }^{12}$. This leads to two consequences, both of which have decentred marriage as a legal concept. The first is growing practical and political pressure to grant non-marital relationships some form of legal 'recognition'. The second is an increased prominence for the legal status of parenthood. The net result is that there is no privileged legal perspective on families - instead, the law now offers a variety of lenses through which family relations may be understood, whether between adults, or between adults and children. The result has been an extension in the ways in which the law now 'sees' families.

\section{De facto legislation}

For example, the number of States and Territories that have enacted legislation granting legal recognition to non-marital relationships has grown considerably, even in the recent past. Family lawyers are probably most familiar with legislation governing the distribution of couples' property on separation. The growing scope of such legislation is well illustrated by recent developments in New South Wales and the ACT, where the range of relationships covered has extended from heterosexual marriage-like cohabitation (as was the case under the old De Facto Relationships Act 1984 (NSW) $^{13}$ ) to, in the case of the ACT's Domestic Relationships Act 1994, relationships of "personal or financial commitment and support of a domestic nature for the material benefit of

\footnotetext{
${ }^{11}$ State Maintenance Acts, mostly enacted in the 1960s, imposed on parents obligations to maintain children born outside marriage.

${ }^{12}$ M.Bittman and J.Pixley, The double life of the family: Myth, hope and experience (1997, Allen \& Unwin), pp.9-13.

${ }^{13}$ s.3 of the De Facto Relationships Act 1984 (NSW) defined 'de facto relationship' as 'the relationship of living or having lived together as husband and wife on a bona fide domestic basis although not married to each other'. In other words, heterosexual marriage was the benchmark. That legislation has now been amended and renamed the Property (Relationships) Act: see Property (Relationships)
} 
[another] ${ }^{14}$. This latter definition is wide enough to include same-sex relations, as well as relationships between individuals who are not actually cohabiting. The recent New South Wales Property Relationships Act similarly includes all 'domestic relationships', which include 'de facto relationships' as well as other 'close personal relationships', within the scope of the legislation ${ }^{15}$. Both elements of the definition are wide enough to include same-sex relationships.

The powers available to a Court under this legislation are often less extensive than those available in respect of married couples under the Family Law Act. In particular, there is no equivalent of the forwardlooking 's.75(2) factors' in State de facto legislation, and the powers to order continuing maintenance are more limited than under the Family Law Act. The reason for this is the perceived need to maintain a privileged status for marriage, and to avoid imposing on unmarried couples obligations that they may not wish to undertake ${ }^{16}$. However, there are signs that this may change. In the ACT, for example, the criteria governing the Court's powers are virtually indistinguishable from those applicable to married couples under the FLA, thereby further reducing the exclusivity of marriage as a legal status ${ }^{17}$, at least in terms of the remedies available under this sort of legislation.

\footnotetext{
Legislation Amendment Act 1999 (NSW). The 1984 definition remains the model in other States with such legislation, save for the ACT.

${ }^{14}$ s.3.

${ }^{15}$ See ss. 4,5 .

${ }^{16}$ The arguments are summarised in H.Finlay, R.Bailey-Harris and M.Otlowski, Family Law in Australia, $5^{\text {th }}$ ed (Butterworths, 1997), p.329. Attempts in New South Wales to read forward-looking factors into the legislation have been reversed: see Evans v Marmont (1997) 21 Fam LR 760.

${ }^{17}$ See, for example, ss.15, 19 Domestic Relationships Act 1994 (ACT), which employs language almost identical to that found in the property distribution provisions of the Family Law Act 1975 (Cth). Family Court authority on property distribution is treated as relevant in ACT courts: see Ferris v Winslade (1998) 22 Fam LR 725. The distinctions between marriage and cohabitation remain evident, however, in the laws relating to post-relationship maintenance.
} 
Heterosexual de facto couples have also achieved parity with married couples in many other areas of law, including those relating to inheritance, immigration, access to infertility treatment and parental responsibilities for children. Indeed, it has been said that Australia is unusual in having 'very high levels of legal recognition of heterosexual unmarried relationships ${ }^{18}$. Gay and lesbian couples, however, are almost universally excluded from these wider forms of legal recognition.

\section{Parenthood}

Along side the growing recognition of non-marital relations between adults has been the growth in the significance of parenthood as a legal status. The most obvious evidence of this is the child support scheme, which creates significant financial obligations on parents whether they are married to the other parent or not ${ }^{19}$. The concept of marriage is wholly absent from the relevant legislation. One consequence of this is that for many couples, especially those with few capital assets, the financial consequences of a separation will be the same whether they are married or not - it is the presence or absence of children that will make the biggest difference. Similarly, the extension of the Family Law Act 1975 (Cth) to include non-marital children ${ }^{20}$ meant that all parents acquired the same legal status ${ }^{21}$ with respect to their children, irrespective of their marital status.

\footnotetext{
${ }^{18}$ Millbank, op.cit., p.129.

${ }^{19}$ For the definition of an 'eligible child', see s.19-21 Child Support (Assessment) Act 1989 (Cth).

${ }^{20}$ Following a referral of powers by the States to the Commonwealth: see the State Commonwealth Powers Acts and the Family Law Amendment Act 1987 (Cth).

${ }^{21}$ Now described as 'parental responsibility': Family Law Act 1975 (Cth), Part VII. The extension of equal parental status to unmarried fathers has proved controversial in other jurisdictions. In the UK, for example, unmarried fathers must first seek an order granting them parental responsibility. The law is under review in England, Scotland and Northern Ireland.
} 
The increased significance of parenthood can be seen as the function of three separate developments. First, it is a necessary consequence of a policy of removing any distinction in the legal treatment of marital and non-marital children, and of eradicating the common law concept of illegitimacy. Australian legislators in the 1970s were amongst the first in the world to bring about this change. One effect of this is that, from the child's point of view, the marital status of the parents is, or should be irrelevant - what matters, in other words, is parenthood, not marriage.

Second, as already noted, the decline in marriage as a social practice has meant that some other legal technique was needed to link men to children, and to impose parental obligations on men, especially obligations of support. Parenthood is a way of tying men into the nonmarital family. As Richard Collier has suggested, the rise of parenthood can be seen as a "widening of the net of paternal authority through facilitating the making of links between men and children just at the time when rising trends of divorce, cohabitation, step-parenthood and serial marriage might appear to have been breaking down the traditional family unit" 22 .

Third, parenthood has become a means by which family law maintains a notional set of links between family members after separation. I will suggest later that family law is increasingly emphasising the maintenance of economic and legal ties between parents and children after separation, as if to create the illusion of permanence in the face of instability. Since, by definition, neither marriage or cohabitation are available for the

${ }^{22}$ R.Collier, Masculinity, Law and the Family (Routledge, 1995), p.207. 
purpose, these continuing links are founded on parenthood. I will return to this point later.

\section{Does legal marriage have a future?}

The growth in the importance of statuses other than marriage raises a number of tensions that will have to be addressed in the future. The first concerns the future of marriage itself. After all, it could be (and has been) argued that the shift towards cohabitation and parenthood, and a reduction in the significance and exclusivity of marriage, are perfectly rational $^{23}$. It ought to make no difference to the way in which arrangements are made for children following parental separation, for example, whether their parents were married to each other or not - the needs of the children are the same. This fact has been formally recognised by the extension in 1987 of the relevant provisions of the Family Law Act to include non-marital children. Equally, when it comes to the distribution of property and income on separation, it could be argued that marriage is also irrelevant - and that instead the important question is whether the gains and losses of a shared life, whether or not it involves children, and whether in or out of marriage, should be allowed to lie where they fall, or should be shared equally or redistributed. This in turn raises the question of whether marriage-based differences should remain a part of the law (ie, so that different rules apply to married couples simply because they are married), or whether the law should aim to address the substantive issues of loss and dependence irrespective of the formal status of the relationship (as the ACT legislation does). The

\footnotetext{
${ }^{23}$ E.Clive, 'Marriage: An unneccessary legal concept?' in J.Eekelaar and S.Katz (eds) Marriage and cohabitation in contemporary societies: Areas of legal, social and economic change (Butterworths, 1980), Ch.8; K.O’Donovan, 'Legal marriage - Who needs it?' (1987) 47 Modern Law Review 112.
} 
latter strategy would have much to commend it - but it would also encounter the resistance of those who seek to preserve the institution of marriage as something separate and special ${ }^{24}$.

Should marriage (or something like it) be made more widely available? Another source of tension will be the techniques by which the law recognises relationships other than heterosexual marriage. As we have seen, existing legislation offers recognition to non-marital relationships on the basis of certain factual criteria, such as the length and quality of cohabitation or the degree of commitment of the parties to each other. Yet, as we have also seen, this 'recognition' falls short of a precise equation of marriage with qualifying forms of cohabitation.

This state of affairs may be justified where parties have exercised a deliberate choice to remain unmarried - but what of those, such as gay couples, for whom heterosexual marriage is not available? Although it is open to such couples to regulate their obligations to each other by contract, no contract will bind the state to recognise the parties as having any special status. This raises the question of whether there should be some other means of conferring status on same-sex relationships, which would have effect both privately and publicly. Possibilities include extending the existing criteria-based regime to same-sex couples (as has already occurred in some jurisdictions), the introduction of voluntary

\footnotetext{
${ }^{24}$ It would also run counter to the trend, discussed below, of increasing certainty through greater reliance on rules. The ACT legislation confers a wide discretion on the Courts to take account of the nature of the relationship in deciding what order to make. Those who advocate the extension of property regimes to all couples, regardless of sexual orientation, acknowledge that it would entail a high degree of discretion in the hands of the decision-maker: see R.Bailey-Harris, 'Law and the unmarried couple - Oppression of liberation?' (1996) 8 Child and Family Law Quarterly 137, at p141. At least where the parties are married, it is more acceptable to make certain generalisations about the principles governing of dissolution.
} 
'registered partnerships ${ }^{25}$ or extending the legal definition of marriage itself to include same-sex couples ${ }^{26}$. This debate has already begun in other jurisdictions, and may not be far away in Australia ${ }^{27}$.

\section{Of course, it is possible that the extension of marriage to wider groups} merely reflects the fact that marriage is no longer a legally significant status. As Glendon has put it, 'the ideologising of the freedom to marry has appeared on the scene just at the moment at when legal marriage is losing much of its traditional significance ${ }^{28}$. Instead, marriage has become increasingly a matter of private ordering, of setting one's own ground rules - in short, of contract rather than status. If this is so, then achieving access to state-sanctioned marriage for gay couples would be a hollow victory. Yet, as Jenni Millbank has shown, there are numerous ways in which marriage automatically creates a significant legal status that is denied to other relationships, especially same-sex relationships ${ }^{29}$.

\footnotetext{
${ }^{25}$ P.Broberg, 'The registered partnership for same-sex couples in Denmark' (1996) 8 Child and Family Law Quarterly 149.

${ }^{26}$ Discussion in the United States has focussed largely on the issue of whether marriage should be extended to same-sex couples (see Millbank, above, at p.129). This is partly because a more highly developed culture of constitutional argument that tends to frame the issue of 'recognition', or lack of it, as an issue of unconstitutional discrimination, and partly because of a weaker tradition of 'recognising' non-marital relationships by means other than marriage. The argument that excluding same-sex couples from marriage is discriminatory were successful in Baehr v Lewin 852 P 2d 44 (Hawaii Supreme Court) and Baehr v Miike 910 P 2d 112 (Hawaii Supreme Court). This triggered a federal legislative response in the shape of the Defense of Marriage Act, which created an exception to the 'full faith and credit' provision of the US Constitution, allowing other States to refuse to recognise interstate same-sex marriages. The issue has generated a vast amount of literature - for an introduction, see M.Strasser, 'Loving the Romer out of Baehr: On acts in defense of marriage and the constitution' (1997) 58 University of Pittsburgh Law Review 279. For a sceptical view of same-sex marriage, see N.Polikoff 'We will get what we ask for: Why legalising gay and lesbian marriage will not "dismantle the legal structure of gender in every marriage" (1993) 79 Virginia Law Review 1535. Constitutional challenges to the legal definition of marriage as heterosexual have also been made in New Zealand and Canada: see the discussion of 'Constitutionalisation', below.

${ }^{27}$ For discussion of 'recognition', see C.Lind 'Pretended families' and the local state in Britain and the USA' (1996) 10 International Journal of Law, Policy and the Family 134; T.Wray 'Lesbian relationships and parenthood: Models for legal recognition of nontraditional families' (1997) 21 Hamline Law Review 127; J.Millbank, op.cit.

${ }^{28}$ M.Glendon, The transformation of family law: State, law and the family in the United States and Western Europe (1989, University of Chicago Press), p.83.

${ }^{29}$ Millbank, ibid.
} 
News of the 'death of marriage' may be premature; at any rate, the truth of that proposition depends on who is hearing the news.

\section{Parenthood: Meaning and effects}

A final source of tension will be the meaning we accord parenthood itself. If it is the case that parenthood is an increasingly important legal status, then what does it mean? It is easy to assume that parenthood is a simple question of biology ${ }^{30}$ - that a child's parents are those who have provided the genetic material that created the embryo that grew into the child. Yet there are at least two reasons why this may not be as straightforward as it appears.

The first is that the creation of embryos is increasingly a matter of external intervention or assistance through infertility treatments - we live, as Marilyn Strathern has put it, 'after nature' ${ }^{31}$ - and one consequence of this is that a focus on nature or biology may be at odds with the social arrangements we wish to reproduce. For example, a woman who has had a fertilised egg created from donated genetic material implanted in her womb, which she then carries to term, will usually wish to do so because she and, often, her partner ${ }^{32}$ want to be considered the resulting child's 'parents', legally and otherwise. The legislative regimes governing assisted reproduction in most Australian States are happy to assist in proclaiming their parenthood, by specifying that the woman carrying the child to term will be deemed the child's mother, while her husband or

\footnotetext{
${ }^{30}$ Yet even this apparently natural assumption is a comparatively recent one - at common law, only the legitimate child (ie, one whose parents were married to each other) was regarded as having a full set of parents. The illegitimate child was filius nullius, a 'child of no-one'.

${ }^{31}$ M.Strathern, After nature: English kinship in the twentieth century (Cambridge UP, 1992).

${ }^{32}$ Mostly male. Attempts to use anti-discrimination legislation to widen access to fertility services to include lesbian couples have met with mixed success: see below.
} 
(male) partner will be the father ${ }^{33}$. Donors of genetic material will be exonerated from parenthood, and would no doubt be alarmed if it were otherwise ${ }^{34}$.

The second complicating factor stems from the culturally specific nature of biological understandings of parenthood. A child has two biological parents, and this mirrors the social expectation that child-rearing will be discharged by two parent household, even if they live in separate households. To that extent, biology underpins notions of kinship, and much of the legal structure of parenthood shares this two-parent premise $^{35}$. Yet this sits uneasily with the child-rearing practices of, for example, Australia's Indigenous communities, for whom parenthood may be indistinguishable from subtle and extended notions of kinship, so that a child may be regarded as having many 'parents', and parenting regarded as a communal rather than individual responsibility. There is a danger that a shift towards parenthood in its crude biological sense will amount to the imposition of one set of cultural values on another ${ }^{36}$.

To sum up the argument so far: the decreased importance of marriage raises questions about what techniques we use to render relationships visible in law and, once visible, what consequences we attach to them; while the increased importance of parenthood raises questions about our

\footnotetext{
${ }^{33}$ s.6(b), Artificial Conception Act 1985 (ACT); s.14, Status of Children Act 1996 (NSW); s.5D Status of Children Act 1978 (NT); ss.15-17 Status of Children Act 1978 (Qld); s.10(d) Family Relationships Act 1975 (SA); s.10C Status of Children Act 1974 (Tas); s.10C-E Status of Children Act 1974 (Vic); s.6 Artificial Conception Act 1985 (WA).

${ }^{34}$ s.ss5(1)(b), 7, Artificial Conception Act 1985 (ACT); s.14 Status of Children Act 1996 (NSW); s.5F Status of Children Act 1978 (NT); s.16(2)(b), 18 Status of Children Act 1978 (Qld); s.10(e)(2) Family Relationships Act 1975 (SA); s.10C(2) Status of Children Act 1974 (Tas); s.10F Status of Children Act 1974 (Vic); s.7(2) Artificial Conception Act 1985 (WA).

${ }^{35}$ J.Dewar, 'Indigenous children and family law' (1997) 19 Adelaide Law Review 217 (discussing Re CP (1997) 21 Fam LR 486).

${ }^{36}$ For a concrete example of why this matters, see G.Reithmuller, 'Conflicting duties: Child support and Australia's maintenance quagmire' (1997) 71 Australian Law Journal 190 (discussing the meaning of a legal 'duty' to maintain a child for the purposes of child support departure orders).
} 
notions of kinship, their relationship to the biological 'facts', and how we can avoid cultural insensitivity. These questions are far from settled.

\section{(b) Legal techniques: From discretion to rules? ${ }^{37}$}

A striking feature of the family law regime created by the FLA 1975 was that it conferred considerable discretion on judges when exercising powers to distribute property on divorce or to make decisions concerning the upbringing of children. Family law did not deal in the vindication of pre-existing rights by constraining the choices available to a decisionmaker at the point of application ${ }^{38}$. Instead, decision-makers were encouraged to look to the consequences of their decision in each particular case and to adjust their decision in the light of the evidence ${ }^{39}$. More than most areas of law, family law was heavily fact-dependent and result-oriented. In the case of property distribution, this was associated with the statutory principle that the Court's powers should be exercised in a way that is 'just and equitable' in the circumstances of each case ${ }^{40}$. Similarly, decisions about children were governed by the general criterion of the child's 'welfare' (now 'best interests') - although in this respect, the 1975 legislation reproduced the laws that it replaced ${ }^{41}$.

\footnotetext{
${ }^{37}$ This section draws on my 'Reducing discretion in family law' (1997) 11 Australian Journal of Family Law 309.

${ }^{38}$ See C.Sunstein, 'Problems with rules' (1995) 83 California Law Review 953, at p.961 and Legal reasoning and political conflict (OUP, 1996) Ch.2 for a discussion of the differences between rules and discretions, and points in between.

${ }^{39}$ See S.Parker, 'Rights and utility in Anglo-Australian Family Law' (1992) 55 Modern Law Review 311 for a discussion of the competing 'ethical impulses' of rights and utility at work in family law.

${ }^{40}$ The discretion is more structured than this suggests: judges must take account of the parties' contributions and then have regard to the s.75(2) factors. See In the marriage of Clauson (1995) 18 Fam LR 693 for a structured approach to decision-making in property matters.

${ }^{41}$ Even so, it is likely that the shift to no-fault divorce has altered judicial interpretations of what a child's 'welfare' requires: aspects of marital behaviour that might once have been considered relevant to welfare issues (eg, the concept of the 'promiscuous parent' being 'handicapped' in child matters: Hutley JA in Barnett $v$ Barnett (1973) 21 FLR 335) has given way to more professionalised understandings.
} 
This is not to suggest that the FLA conferred unconstrained powers of choice on Family Court judges - far from it; but the legislation did leave them with significant choices in implementing the new statutory regime. Indeed, one of the striking features of Family Court jurisprudence over the years has been the extent to which legal principles have been developed through case-law in areas such as contributions to property, the weight to be attached to the s.75(2) factors, the relevance of family violence to property awards or the principles to be applied to cases involving relocation of residence parents or the impact of family violence on children's welfare. Although this process has taken place within the conceptual framework supplied by the legislation, it is almost impossible to detect merely by reading the words of the statute what principles will be applied in a particular case.

Against this background, one of the most noticeable features of family law legislation since the late 1980's has been the tendency to reduce or eliminate discretion from family law decision-making ${ }^{42}$. Examples of this include:

- the introduction of the second stage of the child support scheme in 1989, which removed the Court's jurisdiction to make new orders for child maintenance in respect of certain children and introduced a statutory formula for the assessment of child support liabilities ${ }^{43}$;

- the detailed prescription of principles, standards and factors to be taken into account by a Court when making orders for child

\footnotetext{
${ }^{42}$ This argument is made at greater length in J.Dewar, 'Reducing discretion in family law', op.cit.

${ }^{43}$ Child Support (Assessment) Act 1989 (Cth)
} 
maintenance in respect of children falling outside the child support scheme $^{44}$;

- the introduction in 1996 of the concept of shared parental responsibility for children after divorce, which replaced with an automatic rule what had previously been a matter of judicial choice namely, whether the non-custodial parent should have any formal continuing legal status in relation to the child ${ }^{45}$;

- the inclusion in the new Part VII of the Family Law Act, also in 1996, of the notion of the child's 'right' of contact with both its parents ${ }^{46}$; and

- recent debates surrounding reform of property distribution on divorce, in which presumptive starting points of formal equality in the division of matrimonial property have been proposed ${ }^{47}$.

Taking all these developments together, what seems to be happening is that the deliberately created (ie, legislated) normative content of family law is moving away from conferring legally authorised choice on decision-makers, and is instead seeking to constrain that choice by specifying outcomes more precisely in advance. The question that arises is: why?

\footnotetext{
${ }^{44}$ Division 7, Part VII, Family Law Act 1975 (Cth), which creates a labyrinthine reasoning path for judges to pursue.

${ }^{45}$ The original s.61 of the 1975 Act stated that each parent was a guardian of a child, and that both parents had custody, in either case 'subject to any order of a court for the time being in force'. In practice, orders were usually made granting sole custosdy to one parent, leaving the non-custodial parent with the (limited) authority entailed in guardianship - although even this could be removed by order. The new provisions mean that parental responsibility cannot be taken away or lost, save so far as necessary to give effect to court orders dealing with living arrangements and contact. Parental responsibility itself is probably in any case a wider concept than guardianship. ${ }^{46}$ s.60B(2)(b) Family Law Act 1975 (Cth).

47 Attorney-General's Department, (1999) Property and Family Law, Options for change: A Discussion Paper (Canberra: Commonwealth of Australia)
} 
The retreat from discretion: Efficiency, justice and the 'good divorce' It could be argued that there are three main reasons for this shift.

First, discretion is increasingly seen as being too costly. There are two different kinds of cost arising from discretionary decision-making external costs to the state's welfare system, and internal costs, arising from a perception that discretion makes it harder, and therefore more costly, to settle cases.

Taking external costs first, these arise from the fact that in exercising their discretion, judges decided that it was appropriate to frame orders for property distribution and child maintenance in a way that maximised the state's contribution to family income. Given the fiscal crisis in Australia of the mid-1980s, the then government became concerned at the public costs of supporting the economically weaker members of separated families, and sought to transfer the burden of support back to the family itself. The result was the child support scheme, which removed most child support cases from the Court's jurisdiction and handed over the task of assessment and enforcement of child support to a government agency. Of course, the scheme was not the inevitable result of a desire to curb public expenditure on family breakdown - the same objective could have been achieved by different means, such as including new guidelines to judges about how to exercise their discretion ${ }^{48}$. That option was not

\footnotetext{
${ }^{48}$ Something of this sort has been included in the legislation dealing with the Court's powers to award maintenance in respect of children falling outside the scheme (see Division 7, Part VII, Family Law Act 1975 (Cth)), and in the Court's powers to order departures from statutory child support assessments under s.117 Child Support (Assessment) Act 1989 (Cth). In other jurisdictions, child support issues have been dealt with through guidelines for judicial decision-making. Either way, the result is a constraining of discretion.
} 
chosen for the majority of $\operatorname{cases}^{49}$, however - and the result is a heavily formulaic, bureaucratically administered, rule-based system.

As for internal costs, the argument here is that it is harder to settle disputes against a backdrop of discretionary law as opposed to one of clear rules. Creating a clearer framework of rules, so it is argued, will make cases easier to settle, thereby reducing the burden on the courts, the legal aid fund and the parties' own resources. This argument has been especially prominent in discussions about matrimonial property reform, where the settlement-promoting quality of clearer rules has been used to support the introduction of firmer starting points (such as formal equality) in the distribution of matrimonial property. For example, the Attorney-General's Discussion Paper on matrimonial property reform advances the following argument for such an approach:

a tighter and clearer framework [will make] the process of property settlement more transparent and easier to understand. This will enable people to predict more accurately the likely outcome of a property application and, therefore, assist them in their negotiations. It would also reduce the number of property disputes which need to go to the court for resolution ${ }^{50}$.

The second reason for the shift away from discretion is that there is a growing interest in reviving questions of normative or justificatory frameworks governing the rights and obligations of family members to each other. In short, there is a growing interest in shifting family law back to a rights model. This too has been associated with a shift to rules

\footnotetext{
${ }^{49}$ It was the strategy chosen for child maintenance cases falling outside the child support scheme.
} 
and away from discretion, because there is an affinity (though not a necessary connection) between rights on the one hand and rules as their mode of normative expression on the other: rules appear to offer a guarantee of an outcome - a vindicated claim - in a way that discretion does not ${ }^{51}$. The factors leading to this growth in rights claims are complex, and include domestic political pressure from organised groups (such as fathers' rights groups seeking greater 'equality' in legal treatment, especially in matters concerning children ${ }^{52}$ ); the increased relevance of human rights instruments, especially those dealing with children's rights (see further below); and a growing perception that women have faired poorly under a discretionary regime, and that one response to this is to frame women's claims in terms of rights (eg, in the case of financial provision, to compensation for relationship-induced losses or lost returns on investment in human capital ${ }^{53}$ ) rather than discretionary determinations of contributions or need.

\footnotetext{
${ }^{50}$ Attorney-General's Department (1998) Property and Family Law, Options for change: A Discussion Paper (Canberra: Commonwealth of Australia), at p.39.

${ }^{51}$ It could be argued that there is no intrinsic connection between a utilitarian or consequentialist approach to family law and discretion on the one hand, and rights and rules on the other. For example, it would be possible to have a rights-based model of family law that still invested considerable choice in the judges in deciding how those rights should be vindicated; or that a discretionary system could be seen as giving effect to the rights of the parties, even though that language is not used explicitly. Nevertheless, even though the connection may not be a necessary one, there are observable links between utility as a way of addressing family issues and discretion, and between rights and rules. ${ }^{52}$ See M.Kaye and J.Tolmie, 'Discoursing Dads: The rhetorical devices of Fathers' Rights Groups' (1998) 22 Melbourne University Law Review 162, at pp.164-172 (discussing Fathers' Rights Groups' use of the language of rights and equality).

${ }^{53}$ M.Brinig, 'Property distribution physics: The talisman of time and middle class law' (1997) 31 Family Law Quarterly 93; J.Singer 'Husbands, wives and human capital: Why the shoe won't fit' (1997) 31 Family Law Quarterly 119. See also American Law Institute, Principles of the Law of Family Dissolution: Analysis and Recommendations; Proposed Final Draft Part 1 (ALI, 1997) for a detailed proposal. This sort of debate has been disappointingly absent from the recent debate about property distribution in Australia. Both the initial Discussion Paper on matrimonial property, and the debate that ensued, gave prominence to the issue of equality as a starting point, and passed over the principles that might underlie an 'equity adjustment' in favour of the economically weaker spouse. For an attempt to introduce these concepts in an Australian context, see K.Funder 'Australia: A proposal' in M.Maclean and L.Weitzman (eds) Economic consequences of divorce: The international perspective (OUP, 1992), Ch.6; Family Law Council, Submission on the Property and Family Law Discussion Paper (1999).
} 
A final explanation for the shift away from discretion concerns the role of the state in relation to the family. As O'Donovan has put it, '[s]ince, in liberal society [which is ideologically attached to privacy], the law's role in personal relations is under attack it must retreat into discretion, ${ }^{, 54}$. In other words, the liberal state's own commitment to privacy has made it impossible to formulate clear rules or principles to govern family dissolution - discretion has allowed the underlying issues to remain unresolved . Yet if that is correct, what has changed? It seems that such is the anxiety surrounding the perceived disintegration or decline in 'family values', as well as the financial costs of divorce itself, that families and family law have become central concerns of political debate. As a result, modern legislators have overcome their traditional respect for family 'privacy' and are now more willing than in the late 1970's to issue prescriptions for a 'good divorce' - in particular, that divorcing or separating couples should be rational, altruistic, settlement-minded, cooperative and cost-conscious. Part of this prescription for the new model divorce is enshrined in rules, or norms that are increasingly rule-like ${ }^{55}$.

An example of this growing prescriptiveness of family law legislation concerns relationships between children and the non-resident parent. A striking feature of family law policy in recent years has been the desire to maintain relations between children and the parent with whom they are not living, a relationship that usually involves preserving in law relations

\footnotetext{
${ }^{54}$ K.O’Donovan, Sexual divisions in law (Weidenfeld \& Nicholson, 1985), p.205. See also C.Schneider, 'Moral discourse and the transformation of American family law' (1985) 83 Michigan Law Review 1803 (for the argument that a prominent feature of American family law during the 1970's and early 1980's was 'a diminution in the law's discourse in moral terms about the relations between family members').

${ }^{55}$ For the argument that modern family law is increasingly concerned to 'radiate messages' to a diverse audience of actual and potential litigants, see J.Dewar 'The normal chaos of family law', op.cit., citing M. Galanter, 'Law abounding: Legalisation around the North Atlantic' (1992) 55 Modern Law Review 1 .
} 
between households. This is evident in the child support scheme, which maintains continuing financial responsibilities between non-resident parents and their children, in the new emphasis on continuing and shared parental responsibility, and on children's 'right' to contact with both parents after parental separation ${ }^{56}$. As Smart and Neale have put it:

'..fragments of families are to be found in various households linked by biological and economic bonds, but not necessarily by affection or shared life prospects. We might say that family law is trying to hold the fragments together through the imposition of a new normative order based on genetics and finances, but not on a state-legitimated heterosexual union with its roots in the ideal of Christian marriage ${ }^{57}$.

The prominence given to the maintenance of this parent-child link is a relatively recent phenomenon - and it is noticeable that the relevant legal provisions are rule-like in nature (that liable parents must support their children, that children have a 'right' of contact with the non-resident parent). ${ }^{58}$ In this way, modern family law increasingly seeks to radiate messages about how to divorce well, or how the fragmented family should re-form itself.

\section{An uneasy tension?}

The trend just identified, of a shift towards rules and away from discretion, has not been comprehensive. Instead, there has been a creeping tendency to constrain judicial discretion in some areas, for reasons just explored, but to leave it intact in others. One of the striking

\footnotetext{
${ }^{56}$ s.60B Family Law Act 1975 (Cth)

${ }^{57}$ C.Smart and B.Neale Family fragments? (Polity Press, 1999) at p.181.

${ }^{58}$ See also the discussion of parenthood, above.
} 
consequences of this is that family law now contains a wide variety of normative types - of wide discretions and determinate rules, and many that lie somewhere in between. In part, this can be seen as a product of what Stephen Parker suggests is an oscillation in modern family law between rights and utility ${ }^{59}$; but it can be linked to other more specific factors, such as those of cost reduction. The net result is that it is possible to observe points of tension, as family law seems to offer competing ways of framing the issues it deals with. One example would be the child's 'right' to contact, already discussed, where the issue of a child's contact with a non-resident parent can be framed either as one of the child's best interests, or of the child's rights. Here, the choice of frame may dictate the outcome. Another point of tension is in the area of matrimonial property. There, government proposals for a firmer principle of equal division of property has been greeted with firm opposition on the ground, amongst other things, that firmer rules prevent the individual circumstances of each case from being taken into account. It seems, in short, that there is no widely shared agreement about what family law is 'for' 60 .

\section{(c) New sources of norms: Contractualisation and constitutionalisation}

When the FLA 1975 was enacted, one source of of family law had primacy: namely, the legislation itself, coupled with judicial interpretations of that legislation, and professional understandings or conventions about what judges would be likely to do in any given case. In other words, it was easy to assume a top-down model of legal

\footnotetext{
59 'Rights and utility', above.

${ }^{60}$ Cf B.Hoggett, 'Private lives and public duties: What is family law for?' [1998] Journal of Social Welfare and Family Law 125.
} 
authority, in which legislation and judicial glossing of that legislation were the centre-pieces. However, there are two developments that challenge this model. One is the increased 'contractualisation' of family law; the other is its increased 'constitutionalisation'. Both terms need to be explained - but their combined effect has been to displace domestic legislation as the exclusive source of family law norms.

\section{Contractualisation}

Contractualisation refers to the use of private contracting as a way of ordering domestic relationships, both while they are ongoing and - more significantly for our purposes - when they end. Private contracting around the terms domestic life is not a new phenomenon - couples living together outside marriage have for sometime had a range of legal techniques available to them to make binding arrangements (especially in relation to property and maintenance). Although there may have been doubts about their validity in the early part of this century as a matter of contract law on grounds of public policy ${ }^{61}$, it is now accepted that the mere fact that the parties to, and the subject matter of, a contract is a domestic relationship are not ipso facto bars to its enforceability ${ }^{62}$. Similarly, it has long been legal policy to encourage parties to resolve their own differences on separation by agreement, so as to avoid the need to go to Court (or, as the case may be, the child support agency) although here, the agreements reached are usually enshrined in Court

\footnotetext{
${ }^{61}$ Upfill v Wright [1911] 1 KB 506; Fender v St John Mildmay [1938] AC 1.

${ }^{62}$ Andrews v Parker [1973] Qd R 93; Seidler v Schallhofer [1982] 2 NSWLR 80; Marvin v Marvin 18 Cal 3d 668, 557 P 2d 106 (1976). See S.Parker and J.Dewar, Cohabitants, $4^{\text {th }}$ ed (FT Law \& Tax, 1995) Ch.11. The usual factors vitiating a contract will apply - such as absence of an intention to create legal relations, undue influence, mistake and misrepresentation.
} 
orders rather being left to be enforceable as contracts, and are subject to varying degrees of official scrutiny ${ }^{63}$.

Apart from the examples just mentioned, private contracting has been granted limited scope in the family law context. In particular, it is axiomatic that the court's jurisdiction to make orders for distribution of property on divorce cannot be ousted by an agreement arrived at between the parties at any time before the divorce ${ }^{64}$. Nor does the doctrine of estoppel prevent a party from pressing their claims in court. Confusingly, though, the Courts have said that the existence of an agreement will be relevant to the exercise by the Court of its discretionary powers. This has led to what some consider an unsatisfactory state of affairs - that an agreement dealing with property may turn out to be binding, but only after a Court has pronounced it such ${ }^{65}$.

All this is set to change with the introduction of legislation that will make pre- or post-nuptial agreements binding. According to the Attorney-General's press release announcing the change, parties will be free to make binding agreements before or during marriage, or after separation. The parties will be free to agree 'whatever they like', subject only to a requirement that the parties first obtain legal and financial

\footnotetext{
${ }^{63}$ Rules of court provide for court orders to be made by consent: O.14, Family Law Rules, while primary legislation provides for maintenance agreements: ss.86, 87 Family Law Act 1975 (Cth). Child support legislation also provides for private agreement, but here the rules are complex and unsatisfactory, especially where agreements have not been 'accepted' by, or registered with, the Child Support Registrar: see Deputy Child Support Registrar v Harrison (1995) 20 Fam LR 101 and Bertuch $v$ Lynch (1998) 22 Fam LR 560 for instances of the current muddle.

${ }^{64}$ In the marriage of Woodcock (1997) 21 Fam LR 393. The position is generally different under State de facto legislation, where private agreements can have the effect of excluding the Court's jurisdiction, subject to certain limited safeguards: see Part IV of the relevant legislation in NSW, NT, ACT and SA. In particular, agreements must be certified as having been made with legal advice. In jurisdictions without such legislation, evidence of an agreement would be relevant in ascertaining ownership interests under general law principles, and the agreement itself may be enforceable as a contract. ${ }^{65} \mathrm{Cf}$ the comments of Hoffmann LJ in Pounds v Pounds [1994] 4 All ER 777, quoted in Woodcock (above).
} 
advice. The virtue of the change is that it "enabl[es] parties to take control of their

affairs ... so disputes can be resolved away from Court. ${ }^{66}$ In short, the settlement of disputes is to be privatised in the sense that parties will make their own arrangements away from the scrutiny of a Court (subject only to questions about compliance with requirements of validity) ${ }^{67}$. Each relationship may potentially acquire its own 'proper law', determined by the parties themselves rather than by an outsider armed with discretionary powers of distribution. In this way, private contracting is set to become an autonomous, or semi-autonomous, source of legal norms.

How much it will do so will depend on a range of factors. The first is the extent of consumer demand for agreements excluding the Court.

Anecdotal evidence suggests that the demand is most likely to come from those who are remarrying, those who have significant personal wealth or an expectation of significant inheritance, or those with complex business arrangements involving third parties ${ }^{68}$.

The second is the extent to which the content of agreements will differ significantly from the general principles that would be applied by a judge. Only if there is a significant difference will it be possible to say

\footnotetext{
${ }^{66}$ Attorney-General's Press Release, 19 February 1999, 'Greater certainty in family law property settlements'.

${ }^{67}$ There is a sense in which existing opportunities for private ordering through consent orders already represent a considerable degree of 'privatisation', in that the Court's powers of review of agreements presented for approval may be of limited practical value (but see Brennan J in Harris v Caladine (1991) 172 CLR 84, who suggests that making a consent order in relation to property is 'not automatic' but requires the exercise of a discretion). Nevertheless, the introduction of binding agreements is significant in that it excludes even the Court's theoretical powers of scrutiny of the content (as opposed to formal validity) of the agreement.

${ }^{68}$ C.Murray Earl, 'The New Zealand experience with pre-nuptial agreements', Paper delivered at the $8^{\text {th }}$ National Family Law Conference, Hobart, October 1998.
} 
that agreements have become a genuinely autonomous source of norms. It is possible to envisage two alternative possibilities.

The first is that the requirement of legal advice provides a 'bridge' between the default rules that would apply if there was no agreement, and the bargaining positions of the parties when making their own agreement. To that extent, the default rules will feed into the bargaining process, so that the content of the agreement will at least be influenced by what those default rules are. This would be consistent with the idea that when parties bargain with each other, they do so 'in the shadow of the law, ${ }^{69}$.

Against this, however, are a number of factors suggesting that there may indeed be differences between the content of agreements and the default rules. The first is that the whole point of such agreements is to escape the default rules. It would be odd if parties agreed to divide their property in exactly the way the general law would insist. The only incentive for doing so would be to avoid any contact with the litigation process - but there are devices in place in any event for assisting parties to reach agreement once a divorce is under way.

Also, the mere fact that someone has received legal advice does not mean that they will act on $\mathrm{it}^{70}$. The bargaining chips conferred by legal rules are only one of a number of factors that may affect the dynamics of the bargaining process. Equally important, and quite outside the scope of the

\footnotetext{
${ }^{69}$ R.Mnookin and L.Kornhauser, 'Bargaining in the shadow of the law: The case of divorce' (1979) 88 Yale Law Journal 950.

${ }^{70}$ Belinda Fehlberg's research into 'surety wives' suggests that independent legal advice is rarely an adequate safeguard against entering disadvantageous transactions: Sexually transmitted debt: Surety experience and English Law (OUP, 1997), Ch.6.
} 
default rules to address, are factors affecting parties' bargaining strength - such as the alternatives each party has to not agreeing, or marrying, at all. These factors are likely to place men in stronger bargaining positions than women, and may overpower any bargaining power provided by the default rules ${ }^{71}$.

It remains to be seen which prediction proves more accurate. For the moment, we need only note the potential for the displacement of legislators and judges as the primary source of applicable family law norms, and the possibility of the creation of 'many autonomies' in family law $^{72}$.

\section{Constitutionalisation}

At the same time as norm-creation is being pushed 'down' to the parties through the encouragement of private contracting, so also is it being imposed from 'above' domestic legislatures by human rights norms. These derive from International Treaties or Covenants ${ }^{73}$, or from domestic constitutional guarantees. This process is further advanced in other jurisdictions than in Australia, mainly because Australia has no

\footnotetext{
${ }^{71}$ M.Slaughter, 'Marital bargaining: Implications for legal policy', forthcoming in M.Maclean (ed) Families, Politics and the Law (Hart Publishing). For a sceptical view of pre-nuptial agreements, and a comprehensive review of the literature, see M.Neave, 'Private ordering in Family Law - Will women benefit?' in M.Thornton (ed) Public and private: Feminist legal debates (OUP, 1995), Ch.7; for an argument in their support, see A.Marston, 'Planning for love: The politics of prenuptial agreements' (1997) 49 Stanford Law Review 887. See also R.Field, 'Participation in pre-trial legal negotiations of family disputes: Some issues for women' (1998) 12 Australian Journal of Family Law 240 for a discussion of factors affecting women's negotiating positions in private ordering.

${ }^{72}$ G. Teubner, 'After privatisation?: The many autonomies of private law' in M.Freeman (ed), Legal theory at the end of the millennium (OUP, 1998), p.393: “..the rules and principles of the new family law are responding almost exclusively to [an] extravagent rationality of intimate life and its spontaneous norm formation." (at p.417).

${ }^{73}$ The most significant for our purposes are the UN Convention on the Rights of the Child (CROC), the International Convention on Civil and Political Rights (ICCPR) and the Convention on the Elimination of All Forms of Discrimination Against Women (CEDAW). For discussion, see G.Douglas, 'The significance of international law for the development of family law in England and Wales' in C.Bridge (ed) Family law towards the millennium: Essays for PM Bromley (Butterworths, 1997); J.Behrens and
} 
overriding statement of human rights or civil liberties equivalent to, say, the Canadian Charter of Rights and Freedoms ${ }^{74}$, the UK Human Rights Act $1998^{75}$, the New Zealand Bill of Rights Act $1990^{76}$, or similar constitutional documents setting out basic rights and freedoms ${ }^{77}$. Where such documents exist, they tend to contain provisions that directly or indirectly deal with the family - either by guaranteeing certain familyrelated rights, such as the right to marry, or by creating general principles of non-discrimination. Such instruments are increasingly invoked in arguments over the content or effects of family law provisions - such as the rights of same-sex couples to be allowed to marry or take advantage of certain family laws ${ }^{78}$, or the extent to which parents can use physical punishment to discipline their children ${ }^{79}$.

P.Tahmindjis, 'Family law and human rights' in D.Kinley (ed) Human rights in Australian law: Principles, practice (Federation Press, 1998), Ch.8.

${ }^{74} \mathrm{See}$, for example, AG for Ontario $v M$ and $H$ and others (Sup Ct of Canada, March 1999), upholding the decision of the Ontario Court of Appeal that s.29 of the Ontario Family Law Act 1990, which permits applications for spousal support to be brought only by married couples or heterosexual de factos) infringed s.15(1) Canadian Charter of Rights and Freedoms (guaranteeing equal protection and equal benefit of the law without discrimination) and was therefore of no force or effect. The effect of the decision is to require the Ontario legislature to amend its legislation to permit such claims to be brought by members of same sex partnerships.

${ }^{75}$ The 1998 Act enacts the European Convention on Human Rights as part of domestic law. For analysis of the potential impact of the Convention, see J.Fortin, 'Rights brought home for children' (1999) 62 Modern Law Review 351; J.Fortin, 'The HRA's impact on litigation involving children and their families' (forthcoming in International Family Law); C.Archbold, 'Family law-making and human rights in the United Kingdom' in M.Maclean (ed) Families, Politics and the Law (forthcoming).

${ }^{76}$ In Quilter v AG [1998] 1 NZLR 523, an unsuccessful attempt was made by three lesbian couples to obtain a declaration that they were entitled to be issued with marriage licences. The New Zealand Court of Appeal held that there had been no infringement of s.19 of the New Zealand Bill of Rights Act 1990, even though the New Zealand Human Rights Act 1993 prohibits discrimination against persons on grounds (amongst other things) of sexual orientation: s.21(1)(m).

${ }^{77}$ See, for example, Article 9 of the South African Constitution, which guarantees equal protection and benefit of laws and prohibits unfair discrimination on a number of grounds, including sexual orientation. Article 9 assumes that discrimination is unfair unless it is established that the discrimination is fair. See also s. 75 of the Northern Ireland Act 1998, which requires public authorities in Northern Ireland to 'have due regard to the need to promote equality of opportunity between persons of different ... sexual orientation' (discussed by Archbold, above).

${ }^{78}$ See the Canadian developments discussed above; and in the United States, see Baehr v Lewin (1993) 852 P 2844 (Hawaii Supreme Court ruling that a restriction on same sex marriage constituted sex discrimination under the Hawaii State constitution), and the literature cited at $\mathrm{n} .26$ above.

${ }^{79} A$ v United Kingdom (Human rights: Punishment of child) [1998] 2 FLR 959 (ECHR decision that provisions of Article 3 of the European Convention on Human Rights may have 'horizontal' effect, ie be enforceable between private individuals). See Fortin and Archbold, above, for discussion. 
Yet, although Australia lacks a declaration, or constitutional guarantee, of human rights of the sort increasingly encountered elsewhere, human rights arguments have still had some impact on Australian family law. For example, the chief vehicle for transmitting human rights norms to domestic family law has been the UN Convention on the Rights of the Child (CROC) $)^{80}$. Some of the relevant Articles of the Convention are:

- Article 3 (best interests of the child a primary consideration 'in all actions concerning children');

- Article 9 (child's right to maintain personal relations and direct contact with both parents, except if it is contrary to the child's best interests);

- Article 12 (child's right to express views in all matters affecting the child, where child is capable of forming his or her own views);

- Article 19 (protection from all forms of violence, abuse or neglect); and

- Article 30 (right to enjoy his or her own culture with other members of his or her ethnic group).

Although under Australian law this Convention is not automatically a part of domestic law ${ }^{81}$, it has found its way into domestic law by three separate routes. The first is that some parts of the Convention have been incorporated directly into domestic legislation, especially Part VII of the FLA $1975^{82}$. The second is that the terms of the Convention are relevant to interpretation of domestic laws. In B and B: Family Law Reform Act

\footnotetext{
${ }^{80}$ For an excellent discussion of impact of human rights on family law in Australia, see J.Behrens and P.Tahmindjis, above.

${ }^{81}$ Koowarta v Bjelke-Petersen (1982) 153 CLR 168.

${ }^{82}$ See Behrens and Tahmindjis, op.cit., pp.175-180 for a detailed analysis.
} 
$1995^{83}$, a case involving the geographical 'relocation' of the primary caring parent, the Full Court of the Family Court held that the text of CROC as a whole (and not just those parts enacted as domestic law) was relevant to the interpretation of the Family Law Act, for three reasons:

- that there is a general principle of statutory interpretation that ambiguities or gaps in Commonwealth statutes should be resolved in a way that promotes Australia's obligations under international treaties it has ratified ${ }^{84}$;

- that s.43(c) Family Law Act 1975 requires the Family Court to have regard to 'the need to protect the rights of children and promote their welfare' when exercising its powers, and the terms of CROC are highly relevant in fleshing out the rights of children and hence the duties of the Court under that section; and

- that CROC is a declared instrument appearing in the Schedule to the Human Rights and Equal Opportunity Act and, as such, has 'a special significance in Australian law, ${ }^{85}$.

The third means by which CROC has found its way into domestic law is that the ratification of the Convention has been held to create a

\footnotetext{
${ }^{83}$ (1997) 21 Fam LR 676.

${ }^{84}$ Chu Keng Lim v Minister for Immigration (1992) 176 CLR 1; Minister for Foreign Affiars and Trade $v$ Magno (1992) 112 ALR 529; In the marriage of Murray and Tam; Director, Family Services (ACT) Intervener (1993) 16 Fam LR 982; Minsiter for Immigration and Ethnic Affairs v Teoh (1995) 183 CLR 273.

${ }^{85}$ p.743. The Full Court went on to consider the possible impact of the International Convention on Civil and Political Rights (ICCPR) and the Convention on the Elimination of All Forms of Discrimination Against Women (CEDAW), and specifically the 'rights' they might confer to freedom of movement and protection against unequal treatment of women. The Full Court concluded that, in a relocation case, any such rights must give way to the child's best interests, although the existence of those rights should caution against a 'doctrinaire approach to the question of relocation': p.747.
} 
'legitimate expectation' that its provisions will be adhered to by government officials ${ }^{86}$.

Human rights arguments have found their way into domestic family law by other means. For example, State anti-discrimination laws have been invoked to challenge the refusal by a fertility clinic of services to a lesbian couple ${ }^{87}$. And s.92 of the Australian Constitution, which ensures freedom of 'trade, commerce and intercourse' among States, has been invoked (inconclusively) in argument over the Family Court's power to restrain the relocation of a primary caring parent in the interests of preserving contact between the child and the other non-resident parent ${ }^{88}$. It seems likely that increasing use will be made of arguments of this sort, as the Family Court indicates its willingness to entertain them, and as lawyers become more adept at using them.

When seen in an international context, Australian law could be said to be lagging behind comparable jurisdictions in its concern to protect human rights, especially in the absence of any domestic human rights instrument. Yet even the attenuated means by which human rights norms currently find their way into Australian law are likely to set up two

\footnotetext{
${ }^{86}$ Minister of State for Immigration and Ethnic Affairs v Teoh 183 CLR 273. See M Allars, 'One small step for legal doctrine, one giant leap towards integrity in government: Teoh's case and the internationalisation of administrative law' (1995) 17 Sydney Law Review 204.

${ }^{87}$ See $J M v Q F G$ and $G K$ [1998] QCA 228. Here a lesbian couple challenged a clinic's refusal to provide fertility services under the Anti-Discrimination Act 1991 (Qld). The argument succeeded before the Queensland Anti-Discrimination Tribunal, but that decision was overturned (at least so far as it was based on a finding of direct discrimination) by the Queensland Court of Appeal, which remitted the matter to the Tribunal for rehearing on the matter of indirect discrimination and the applicability of the 'welfare measures' provision in the anti-discrimination legislation. For discussion of access by lesbian couples to fertility services, see J.Millbank, 'Every sperm is sacred?' (1997) 22 Alternative Law Journal 126.

${ }^{88}$ AIFS v AMS (1999) 24 Fam LR 756. See in particular the distinction drawn by Gaudron J between orders necessary for a child's protection (which would not contravene s.92) and orders made to promote the child's 'best interests' (which may), at p.781. Gaudron J also suggests that restrictions that operate in a discriminatory way (eg, restrictions that bear more heavily on a woman than a man) would also fall foul of s.92.
} 
different kinds of tension. The first is that, already noted in our discussion of rules and discretion, between rights-based arguments and the more traditional welfarist, or utilitarian, stance of family law. Family law, and family lawyers, are accustomed to taking each case as it comes, and to fine-tuning an outcome according to the individual circumstances of each case; whereas rights demand vindication, irrespective of those circumstances. That is the whole point about rights - that they cannot be 'trumped' by other considerations. An increased role for rights-based arguments (at least, those which would seem to reduce the choice available to a decision-maker) seems to require a change of mind-set on the part of family lawyers, as well as offering a rich resource for legal argument.

The second area of tension is that between the vindication of rights and the maintenance of existing social institutions, such as marriage and the autonomous 'private' family. As Behrens and Tahmindjis point out, concepts of rights, and especially children's rights, may be seen by some as posing fundamental threats to family autonomy from state interference, or to parental authority ${ }^{89}$. Allied to this are the transformative effects of rights-based arguments on social institutions such as marriage. Rights are traceable ultimately to individuals. Rightsbased arguments therefore give priority to the individual's right to participate in those social institutions, such as marriage, rather than to the preservation of the institution itself in a particular form. It is no accident, for example, that one effect of anti-discrimination arguments has been, or is likely to be, a radical redefinition of marriage to include same-sex couples. To the extent, then, that rights challenge existing notions of

\footnotetext{
${ }^{89}$ Behrens and Tahmindjis, 'Family law and human rights', above, at p.170.
} 
privacy, or give priority to individual claims over the maintenance of social institutions, they are likely to encounter opposition from those would prefer to uphold traditional values of family autonomy, parental authority and marriage as exclusively heterosexual ${ }^{90}$.

This may be little more than an inevitable feature our times, of what some social theorists are now calling the era of late modernity ${ }^{91}$. Ulrich Beck, for example, argues that as modern society progressively realises its ideals (such as sexual equality or non-discrimination), it simultaneously dissolves the traditional structures on which it has previously depended, such as the sexual division of labour: '..the advancement and dissolution of industrial society coincide. This is exactly the process of reflexive modernisation ${ }^{, 92}$ It is perhaps precisely because we live in a society characterised by the collapse of nature and tradition, what Beck has called the 'risk society', that we have turned to 'rights' as a symbolic ordering of relations, and as a way of anchoring responsibilities, just as the traditional mechanisms for doing so are fast disappearing As Bill MacNeill has suggested, the growth in rights talk may be a 'symptom' of the anxieties that this shift in social ordering brings in its train ${ }^{93}$. In other words, perhaps rights talk is not

\footnotetext{
${ }^{90}$ The language of rights may have powerful and unexpected consequences. For example, the use of the concept of a child's 'right' to contact in s.60B of Part VII of the Family Law Act 1975 (Cth) has seemingly created a significantly higher 'expectation of entitlement' on the part of those (mainly fathers) with whom such contact would occur: see J.Dewar and S.Parker (with D.Cooper and B.Tynan) Parenting, planning and partnership:A study of the impact of the Family Law reform Act 1995 (Griffith University, 1999); and H.Rhoades, R.Graycar and M.Harrison, The Family Law Reform Act 1995: Can changing legislation change legal culture, legal practice and community expectations? (Interim Report, April 1999; University of Sydney/Family Court of Australia).

${ }^{91}$ U.Beck, Risk society: Towards a new modernity (Sage, 1992).

${ }^{92}$ Ibid., p.104. See also A.Giddens, 'Risk and responsibility' (1999) 62 Modern Law Review 1.

93 '...in the era of postmodernity, rights discourse may be one of the few if not the only grand recits left with which to narrate the nation': W.MacNeil, 'Enjoy your rights! Three cases from the postcolonial Commonwealth' (1997) 9 Public Culture 377 at p.379.
} 
transformative as such, but merely refelective of deeper shifts that law has only limited capacity to control or influence.

\section{Autonomy and rights: An uneasy tension?}

To sum up this part of the argument, it seems that the welfarist paternalism of family law characteristic of the mid-1970s is increasingly giving way to private norm formation and to universal human rights. Yet it is hard not to see these two new developments as themselves in potential conflict with each other - for surely one of the dangers of increasing the scope for private autonomy is that human rights are more easily abused or overlooked behind closed doors; or, conversely, that applying universal human rights norms will obliterate respect for difference $^{94}$. Resolving this potential conflict - between sensitivity to autonomy and difference, while upholding basic values of fairness and justice - is one of the central tasks of modern family law and its administration.

\section{(d) The fragmentation of the family law system}

Running through the preceding discussion of the 'contractualisation' and 'constitutionalisation' of family law is a subsidiary one of fragmentation. The preceding section suggested that in place of a unitary family law regime, with a single source of legal norms, we now have multiple sources of norms. One consequence of this is that there is increased potential for tension between those different normative types - in particular, human rights norms may sit uneasily with the 'utility' thinking of much family law. In this section, I pursue this theme of fragmentation

\footnotetext{
${ }^{94}$ These tensions are not by any means confined to Australia, or even to 'western' democracies: see T.Nhlapo, 'Cultural diversity, human rights and the family in contemporary Africa: Lessons from the South African Constitutional debate' (1995) 9 International Journal of Law and the Family 208.
} 
further, but this time at the level of family law as a working 'system', comprised of human actors and institutions, rather than as a bundle of norms of increasingly diverse origin.

One way of understanding fragmentation in this sense is to consider the idea that when parties bargain with each other over the consequences of divorce, they do so 'in the shadow of the law'. This idea comes from a well-known article, published in 1979, by Mnookin and Kornhauser, called 'Bargaining in the shadow of the law: The case of divorce' ${ }^{95}$. In it, the authors sought to develop a theory of how divorcing couples bargain with each other in a divorce context. In particular, they were interested in the factors that might affect the bargaining process. They identified five such factors: parental preferences concerning post-divorce arrangements, the bargaining endowments (or bargaining positions) created by legal rules, the degree of uncertainty in the outcome if the parties went to court coupled with their attitudes to risk, the transaction costs entailed in going to Court and the parties' ability to bear them, and the parties' disposition to engage in strategic behaviour. For present purposes, I am interested in their second factor - the bargaining positions created by legal rules.

The authors assume that these are in some sense 'fixed', save in so far as they are affected by the other four factors they identify. In other words, there is an underlying assumption that legal rules bear the same meaning, or carry the same weight, for all parties, and they will be given the same meaning wherever they are applied ${ }^{96}$. Yet an interesting and important

\footnotetext{
95 (1979) 88 Yale Law Journal 950.

${ }^{96}$ Mnookin and Kornhauser themselves acknowledge that the endowments conferred by law may be uncertain because of the discretionary nature of the law (pp.969-971) - but this is a different point from the one being made here, which is that the way in which the uncertainty is made determinate will vary according to where the parties are in the system.
} 
feature of the family law 'system' as it operates in Australia (and, probably, elsewhere) is that it is becoming increasingly fragmented, so that even the very meaning given to legal rules may vary according to where in the system they are being applied: the evenness in interpretation assumed by Mnookin and Kornhauser may not turn out to be the case in practice. To put it another way, there are now many different ways in which 'meaning' can be attached to legal rules in a way that may significantly alter the bargaining positions they create. So what are the causes of this fragmentation, and what are its consequences? I want to identify three such causes (without suggesting that these are the only ones).

\section{Private ordering}

Australian family law, both in policy and practice, places heavy emphasis on encouraging parties to settle their own differences without going to Court. There are a number of ways in which parties can be assisted to do this, including referral to mediation or counselling, or through negotiations between lawyers. The Family Court also has its own procedures for encouraging parties to settle. The success of these various methods is evident in the fact that $95 \%$ of matters settle without requiring a full trial in front of a judge ${ }^{97}$. In these cases, the parties will usually formalise their agreement in a Court order which is then approved by the Court as a consent order. Another method of private ordering that will shortly be available, as we have seen, is for parties to make binding prenuptial agreements that would oust the jurisdiction of the Court altogether. 
How does this relate to the question of fragmentation? The answer lies in the fact that private ordering of disputes takes place in a growing range of arenas - including solicitors' offices, legal aid conferences, counselling and mediation inside and outside the Family Court, as well as at formal stages on the Family Court's case-management pathway. Yet, contrary to the assumption implicit in the metaphor of 'bargaining in the shadow of the law', the meaning attached to legal provisions may vary according to the arena in which they are being invoked. The meanings given to law in one arena may be determined in ways that may be quite autonomous from meanings that would be given in other parts of the system ${ }^{98}$. For example, empirical research increasingly suggests that negotiations between lawyers may take place on the basis of assumptions about the meaning of legal provisions that may bear only a tenuous relationship to 'official' interpretations of legal provisions (for example, by judges $)^{99}$; and that these inter-lawyer negotiations may form an independent source of conventions and assumptions about legal interpretation that are just as powerful in practice as those that come from 'above' ${ }^{100}$. Similarly, counsellors or mediators may seek to place interpretations on legal provisions that either suit their own professional frame of reference (eg, as trained social workers or psychologists) or

\footnotetext{
${ }^{97}$ Family Court of Australia, Response of the Family Court of Australia to the Attorney-General's Department paper on Primary Dispute Resolution services in family law (1997, FCoA), p.xvii.

${ }^{98}$ J.Wade, 'Forever bargaining in the shadow of the law: Who sells solid shadows? (Who advises what, how and when?)' (1998) 12 AJFL 256.

${ }^{99}$ For a striking example of this, see J.Dewar and S.Parker (with D.Cooper and B.Tynan) Parenting, planning and partnership:A study of the impact of the Family Law Reform Act 1995 (Griffith University, 1999) and the discussion of the 'reverse effect' of the Full Court decision in $B v B$ (discussed above). Professional understandings of legal meaning, especially when translated into concrete strategies, may be at odds with judicial interpretation. For another example of the gap that might exist between 'official' divorce law and professional culture, see C.Archbold, P.McKee and C.White, 'Divorce law and divorce culture - the case of Northern Ireland' (1998) 10 Child and Family Law Quarterly 377.

100 'Negotiation between solicitors is a 'semi-autonomous' process which takes place in the shadows of, and itself casts shadows on, other such processes': R.Ingleby, Solicitors and divorce (OUP, 1992) at p.155; see also M.Melli, H.Erlanger and E.Chambliss 'The process of negotiation: An exploratory investigation in the context of no-fault divorce' (1988) 40 Rutgers Law Review 1133.
} 
which serve their own objectives in the counselling or mediation process $^{101}$.

In other words, the forum in large part determines meaning of legal rules - which will in turn affect the type of bargaining positions they confer. The heavy emphasis on alternative, or 'primary', dispute resolution in family law is likely to continue, and so increase the diversity of interpretive fora ${ }^{102}$.

\section{Legal aid}

Another source of fragmentation, and one which is related to the immediately preceding discussion, relates to the impact of legal aid policies on the operation of the family law system. Legal aid is of crucial significance in family law - it is the largest single head of Commonwealth expenditure on legal aid in Australia, and many family law litigants are able to access the system only with some form of assistance from legal aid authorities. The overall shape of legal aid policy is therefore crucial in determining the shape and functioning of the family law system.

In Australia, the administration of legal aid is a matter for State legal aid authorities, so it is difficult to generalise across all States and Territories. However, the availability of legal aid in family law matters has, since 1997, been governed by the application of Commonwealth legal aid guidelines, so that some generalisations can be drawn - even though the way in which legal aid is then spent, once eligibility is established, is matter for the administering authority.

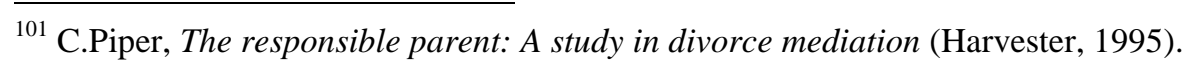


For present purposes, we need only note that if someone is dependent on legal aid, it is increasingly likely that they will be in a different strategic position from a privately funded litigant. Depending on local legal aid policies, they will either find that their grants of aid are 'capped' at a certain level, so that once that level has been reached all forms of aid will be withdrawn; or they will find that legal aid is not available at all for certain aspects of proceedings; or they will find that they will be eligible only for limited forms of assistance, such as legal aid conferencing (a form of mediation) ${ }^{103}$. The net result of this is that legally aided and privately funded litigants are not equal in their abilities to access the core of the family law system - so, to the extent that the metaphor of 'bargaining in the shadow of the law' assumes that they are, it is once again inaccurate. Indeed, under this bargaining model, what makes good the bargaining positions conferred by the law is the fact that they are theoretically enforceable in Court - yet the state of legal aid in Australia today makes that possibility not even a theoretical one for many litigants (except as a litigant in person, on which see more below) ${ }^{104}$.

So, what we have here is fragmentation, not of interpretations, but of individual's ability to access the core of the system (the Court) for authoritative determinations of the parties' rights and entitlements. This ability is increasingly unevenly spread, so to the extent that being able to

\footnotetext{
${ }^{102}$ A good example of this is the introduction of arbitration.

103 J.Dewar, J.Giddings and S.Parker 'The impact of legal aid changes on the practice of family law' (1999) 13 Australian Journal of Family Law 33.

${ }^{104}$ Of course, it is possible that law exerts a distinct shadow over legal aid-instigated conferencing or mediation; but it is just as possible that it does not. What little evidence there is concerning the influence of legal norms on mediation suggests that the shadow of law may be indistinct: see, for example, Piper, above.
} 
get to Court is necessary to make good the bargaining positions conferred by law, those bargaining positions are themselves unevenly spread.

\section{Entry points}

A final source of fragmentation relates to the way in which litigants enter the family law system in the first place. Research has shown that this can have a significant effect on the way in which matters are subsequently resolved $^{105}$. To begin with, the entry point may determine whether a party regards their case as raising an issue that can or should be resolved by legal means. If the first point of contact is with a lawyer, then there is a higher likelihood that a legal solution will be sought, and that the nature of that legal solution will be different, than cases in which the first point of contact is with someone other than a lawyer. Of course, a party's choice of first contact may itself reflect their own predispositions as to how they want their matter resolved - there is evidence, for example that while some parties want their lawyers to take an aggressive, partisan approach, others want their lawyers to be more conciliatory in style, or may not want a lawyer at all - and their choice of first contact will reflect those predispositions ${ }^{106}$. Initial entry point is not, therefore, an independent variable; but once that choice is made, it has observable consequences. This is particularly so where the litigant is unrepresented (as many in the Family Court now are ${ }^{107}$ ) - in such cases, the extent to which a litigant operates within the shadow of the law at all is likely to vary from person to person.

\footnotetext{
${ }^{105}$ Dewar and Parker, op.cit.; H.Jacob, 'The elusive shadow of the law' (1992) 26 Law \& Society Review 565. Jacob argues that the role of law in divorce negotiations is contingent on a range of variables, such as the client's initial 'framing' of their problem as one that does or does not require a legalistic resolution

${ }^{106}$ G.Davis, Partisans and mediators (1988, OUP)

${ }^{107}$ B.Smith, ' 1998 study of the effects of legal aid cuts on the Family Court of Australia and its litigants', Research Report No19 (1999, FCoA), pp.20-1.
} 
In a sense, this merely confirms Mnookin and Kornhauser's insight that a full bargaining theory must take account of individual preferences as to how to resolve matters, and of a party's willingness to engage in strategic behaviour. Yet it also suggests that the imprint of law itself, and of the shadow it casts, will be variable according to the route adopted by individuals through the litigation process. Again, the shadow(s) cast by law will not be the same for everyone.

\section{Implications?}

So, what are the consequences of these different forms of fragmentation? At a theoretical level, one consequence is that the traditional 'top-down' model of law, in which legislators and judges have hierarchical superiority in the production of authoritative legal meaning over all other parts of the system, may have to be reconsidered. Instead, there are multiple sites of legal interpretation, each operating side-by-side and interacting with each other in a variety of ways. Instead of a single shadow cast by law, as Mnookin and Kornhauser presupposed, there are instead many shadows, with no single shadow covering the whole system This could be thought of as a horizontal rather than hierarchical view of the system ${ }^{108}$. But at a practical level, does any of this really matter? It will be suggested that it does, and that it is possible to take a positive or negative view of how and why.

On a positive view, it could be argued that what I have referred to here as fragmentation is in fact an example of how the law is facilitating private

\footnotetext{
${ }^{108}$ For further elaboration of the notion of 'horizontalisation', see Dewar and Parker, op.cit.; and see W.Murphy, The oldest social science: Configurations of law and modernity (OUP, 1997), Ch.6; P.Goodrich, 'Social science and the displacement of law' (1998) 32 Law \& Society Review 473.
} 
choice, and of being responsive to individual difference. It is an instance of how family law has become more responsive to the needs of those it affects and is consistent with the view that private law in general should develop so as to permit 'many autonomies' rather than operating in a traditional 'top-down' way, by imposing one set of values and ideas on everyone.

Yet on a negative view, it could be said to mark the decline of an important aspect of legalism, namely, the idea that all are equal before the law. Instead, the abandonment of litigants to their 'many autonomies' is a form of the 're-privatisation' of family law, in which the state withdraws from guaranteeing the fairness of outcomes when judged against an objective benchmark and assumes instead that parties are equally capable of defining and defending their own view of what is fair. As such, it overlooks inequalities in bargaining power and entrenches those inequalities in legal policy. The increased emphasis on private ordering and the steady withdrawal of legal aid for court proceedings may simply alter the terms of bargaining in favour the more powerful who are often men rather than women.

There is a sense in which the positive and negative views of fragmentation merely give expression to a more deeply-seated tension in our modern understandings of legality. On the one hand, there is a conventional understanding of what it means to live in a liberal democracy under the rule of law, in which equality before the law, and equality of access to law, are cornerstones of conceptions of citizenship and the bedrocks on which the legitimacy of our system of government is 
based $^{109}$. On this view, Courts and related institutions are crucial arenas of social integration, and law a central framework for making sense of our social and institutional life ${ }^{110}$. On the other hand, there is the need to respond to and accommodate individual difference, and to guard against the danger that conventional liberal legalism does not become a by-word for majoritarianism, or the imposition of the values of the many on the many 'others'. On this view, law is merely instrumental, a way of facilitating exchange and setting the tone or background noise for private exchanges ${ }^{111}$.

The trick, I suspect, is to preserve the best of both ideals of legality, while striving to avoid the oppressive potential of either - to seek, in other words, to prevent the oppression of the weak by the strong at either the collective or individual level. I suspect that we are some way from this. At the individual level in particular, changes in legal aid in the last few years have generated profound concerns about the legal system's ability to guard against those dangers ${ }^{112}$. Although there are now signs of a willingness at government level to articulate a clear policy direction for legal aid, it is striking how conventional notions of level playing field seem now to have been explicitly abandoned. Instead, government policy seems to be to approach these substantive issues of fairness by oblique means - through the language, for example, of 'accountability,

\footnotetext{
${ }^{109}$ See D.Luban Lawyers and Justice: An ethical study (1988, Princeton UP), Chs.11 and 12.

${ }^{110}$ C.Greenhouse, 'Nature is to culture as praying is to suing: Legal pluralism in an American suburb' (1982) 20 Journal of Legal Pluralism 17.

111 cf. Teubner, 'After privatisation', above.

${ }^{112}$ C.Caruana, Hitting the ceiling: Springvale Legal Service Report on funding limits in legally aided Family Law matters (1998, Springvale legal Service); J.Dewar, S.Parker and J.Giddings, 'The impact of legal aid changes on family law practice' (1999) 13 Australian Journal of Family Law 33; N.Seaman, Fair shares? Barriers to equitable property settlements for women (1999, WLSN/NACLC), especially Chs. 7 and 8.
} 
accessibility and quality' of government-funded legal services ${ }^{113}$. This is not necessarily a cause for regret (the old ideal was one that was probably rarely realised in any case, so in a sense rhetoric has merely caught up with practice) - but it does lead us to ask whether the new language of governmental efficiency, transparency and quality control, proves to be an adequate aspirational substitute for the old.

\section{Another way of doing politics?}

In portraying family law as 'discontented', I have perhaps painted a rather gloomy picture - of an area of law that is fraught with contradiction, inconsistency and uncertainty over what seem like basic principles, and where basic tenets of legality seem to be under threat. To those for whom family law has never been 'real law' this will come as no surprise, but instead as grim confirmation of what they always suspected - that it is messy, unprincipled and too closely engaged with human passions to be worthy of serious enquiry. But I want to end on a more positive note, and to suggest that that its messiness and discontentedness point are the very reasons why it makes for such a fascinating and dynamic area of study.

My starting point in this is that the terms on which family life should be lived are the subject of intense disagreement and radical uncertainty. At the same time, family life itself is more fluid and diverse than ever before. So, not only do we lack concensus, we also lack a clear object or focus. On one view, this might be considered a problem for family law

\footnotetext{
${ }^{113}$ Keynote address by the Attorney-General, Legal Aid Forum - Towards 2010, 'A Modern Legal Aid Framework - the Commonwealth Government's Strategy for Reform of Legal Aid Services in Australia', $21^{\text {st }}$ April 1999.
} 
and policy - for how are we to devise legislation against such a background of intense uncertainty?

There is a real risk in these conditions of family law being hijacked by a certain form of ideological or doctrinaire rhetoric - legislation that enshrines an impossible ideal of familial or divorcing behaviour, and then proceeds merely to punish those who are unable to comply. Something like this was about to happen in the United Kingdom, with the enactment of the Family Law Act 1996. This legislation sought to achieve a variety of objectives that can only be described as social engineering, or what Clifford Geertz would call 'ideological retraditionalisation, ${ }^{114}$. Divorce was to be made harder to get, by various procedural devices; divorcing parties were to be coerced into being reasonable (and thereby avoid consulting lawyers), by a complex combination of sticks and carrots; and there were to be attempts to discourage divorce altogether by requiring parties to face the realities of their post-separation circumstances sooner rather than later. Not surprisingly, perhaps, all the evidence from the pre-implementation pilot studies was that this would not work: that it was not, after all, possible to coerce people into being reasonable and co-operative; and that the more people knew about the divorce process, the more they wanted a lawyer to help them through it. As a result, the Labour government has decided to delay implementation of the legislation indefinitely ${ }^{115}$.

The demise of the Family Law Act 1996 in the United Kingdom is a sign of hope that family law legislation that seeks to impose a specific

\footnotetext{
${ }^{114}$ C.Geertz, 'Ideology as cultural system' in D.Apter (ed) Ideology and discontent (1964, Free Press). ${ }^{115}$ Lord Chancellor's Department Press release, 'Implementation of Family Law Act Part II delayed', June $17^{\text {th }} 1999$.
} 
ideology of proper divorcing behaviour will not work. It offers hope for a different vision of family law, as an arena in which our disagreements get to be worked through and debated, an opportunity to conduct a continuing conversation amongst ourselves about the terms on which our intimate lives are to be lived ${ }^{116}$. In short, family law should become, and should be celebrated as, what Marc Galanter has called 'a second form of politics', which 'provides resources and opportunities for the pursuit of our competing commitments, ${ }^{117}$.

But the form of politics offered by law, and family law, is distinctive, and here we come to why I think family law, and family lawyers, have a major role to play in debates around the family of the sort I have been discussing. As already noted, family issues are perhaps the ones that generate more passion, intensity of feeling and disagreement than any other. It is a realm in which big ideas are in play, where the passions are engaged and in which the stakes are high for us all. One of the virtues of legal debate is that it calls us back to the level of practicality, or functionality - the question, in other words, of what will work. Law's uniqueness, and perhaps its great achievement, lies in its ability to provide a context for what Cass Sunstein calls 'incompletely theorised agreements'. This is what happens when 'people diverge on some (relatively) high-level proposition, [but] might be able to agree when they lower the level of abstraction, ${ }^{118}$.

As Sunstein points out, this 'lowering of the level of abstraction' is the very stuff of legal reasoning, and plays a vital role in securing the

\footnotetext{
${ }^{116}$ K.O’Donovan, Family law matters (1993, Pluto Press), Ch.7.

${ }^{117}$ Galanter, 'Law abounding', op.cit. at p.23.

${ }^{118}$ C.Sunstein, Legal reasoning and political conflict (1996, OUP), p.37.
} 
legitimacy of a political system against a background of a radical division of opinion. By providing a bridge between the world of ideas and large scale social projects on the one hand, and the world of strategies and practices on the other, law opens up space for agreement where none might have existed before ${ }^{119}$. This, I suggest, is the distinctive contribution of lawyers to family disputes, at both an individual and collective level. ${ }^{120}$ By shifting the focus to the practical or the functional, legal discourse helps us to find a common ground. Indeed, given the level and intensity of disagreement about family issues, it may be our only hope.

\footnotetext{
${ }^{119}$ Conversely, where legislation seeks to deal in 'big ideas', such as children's rights, the effects can be unpredictable and divisive. This is not to deny the legitimacy of those ideas, merely to query whether it is appropriate that they should be incorporated into concrete legal discourse.

${ }^{120} \mathrm{By}$ 'lawyers' here I mean anyone who is engaged in dispute resolution in a legal setting. In a family law context, this would include counsellors and mediators. Some may be surprised at this usage, but I suspect there are more similarities between these different professional groups in their approaches to dispute resolution than some would suggest. The tendency is often to emphasise the differences (as I have here at various points), but we should not overlook those similarities.
} 